\title{
POTENSI PERGURUAN TINGGI ISLAM SEBAGAI LEMBAGA IJTIHAD JAMA'I
}

\author{
Junaidi Hamsyah \\ Fakultas Tarbiyah dan Ilmu Keguruan IAIN Bengkulu; email: junaidihamsyahbkl@yahoo.co.id \\ Diterima: 20 Agustus 2016. Disetujui: 28 Oktober 2016. Dipublikasikan: Desember 2016
}

\begin{abstract}
The responsibility of moslem to translate the holy Qur'an and Hadist as the aswers to all life problematics is in the hands of intelectual moslem. Islamic universities are formal institutions that not only play a role in education but also have the potential to become the most authoritative da'wah institution to issue legal decisions. Academic community are individuals who have been equipped with adequate tools of ijtihad, that is comprehensive and holistic science disciplines. Islamic universities, moreover, have qualified to become ijtihad jama'i institutions that are needed by modern Muslims.
\end{abstract}

\begin{abstract}
Abstrak
Tanggung jawab umat Islam untuk menerjemahkan Alquran dan Hadist sebagai jawaban segala problematika hidup ada di tangan muslim intelek. Perguruan tinggi Islam adalah lembaga formal yang tidak hanya berperan dalam pendidikan, namun juga berpotensi menjadi institusi dakwah paling otoritatif untuk mengeluarkan keputusan hukum. Komunitas akademis adalah individu yang telah dilengkapi dengan peralatan ijtihad yang memadai, yaitu disiplin sains yang komprehensif dan holistik. Universitas Islam, apalagi, telah memenuhi syarat untuk menjadi ijtihad institusi jama'i yang dibutuhkan oleh umat Islam modern.
\end{abstract}

Kata kunci:perguruan tinggi, ijtihad jama'i, modernitas.

(C) 2016 URPI, FTK IAIN Raden Intan Lampung

\section{PENDAHULUAN}

Abad XXI adalah era ilmu pengetahuan sains dan teknologi. Perkembangan paling pesat ditunjukkan oleh dunia Barat yang sampai hari ini belum tertandingi. Budaya belajar dan berkarya untuk terus mengeksplorasi pengetahuan tentang alam kosmos, bumi, bahkan anatomi tubuh manusia sendiri di Barat sangat tinggi. Seiring dengan isu globalisasi dan pasar bebas, tradisi sains dan teknologi di Barat modern merembes ke dunia-dunia Timu, menjadi konsumsi negara-negara berkembang, dan menjadi kiblat ilmu pengetahuan eksakta maupun sosial. Produk-produk negara-negara maju itupun menjadi sangat melekat dengan aktifitas sehari-hari masyarakat.

Isu globalisasi dan pasar bebas, pada akhirnya, bukan sekadar persoalan kebudayaan dan ekonomi politik melainkan menjadi simbol sumber perubahan masyarakat dunia. Perubahan yang mencakup hampir setiap aspek kehidupan tidak bisa dibendang dengan bentuk larangan apapun kecuali sebagian negara yang menyatakan mengisolasi diri dari pengaruh Barat. Di beberapa negara tertentu terdapat kebijakan hukum yang melarang demokrasi dan transparansi sehingga celah masuknya arus kebudayaan dan pengaruh Barat semakin sempit.

Kebetulan historis mengantarkan Indonesia pada status sebagai negara demokrasi, dan nyaris sebagian pakar menyebut status Indonesia telah mengadopsi demokrasi liberal sekaligus sistem ekonomi pasar bebas. Dengan membanjirnya investasi-investasi maupun produk-produk teknologi mutakhir dari negara-negara asing menandakan bahwa Indonesia setidaknya bukan negara yang menutup diri atau mengisolasi dari pengaruh negara-negara maju tersebut. Dengan satu konsekuensi nyata bahwa 
perubahan di dalam negeri merupakan keniscayaan yang tidak bisa dihentikan seiring perkembangan arus perubahan dunia.

Dalam konteks arus perubahan tersebut, kebutuhan umat muslim akan jawaban Islam tentang semua persoalan yang juga cenderung terus berubah sangatlah besar. Tuntutan agar Islam mampu merespon satu persatu persoalan umat dirasakan langsung oleh kaum intelektual, baik dari kalangan akademisi maupun agamawan. Para pemikir Islam sama-sama dihantui perasaan takut bila suatu saat Islam dibuat melempen dan mandeg oleh para pengikutnya sendiridengan cara-cara yang ironis, yaitu menutup pintu ijtihad dan istinbath alhukm (proses penggalian hukum dari sumber al-Quran dan Hadits melalui metode-metode yang sudah baku).

Di Indonesia, pintu ijtihad tidak pernah tertutup sebagaimana yang digembar-gemborkan selama ini. Setiap kali perusahaan-perusahan makanan dan minuman, sebagai contoh, mengeluarkan produk terbaru mereka untuk dipasarkan kepada konsumen, Majelis Ulama Indonesia (MUI) mengeluarkan fatwa hukum dan melabeli produk tersebut sebagai halal atau haram. Pondok-pondok pesantren, di Jawa Timur misalnya,juga sering menerbitkankarya-karya kompilasi yang berisi fatwa-fatwa hukum versi mereka dan ditujukan untuk menjawab fenomena-fenomena sosial kontemporer umat muslim. Beberapa kasus menunjukkan bahwa pintu ijtihad terus terbuka, tentu saja dengan variasi metodologi atau manhaj.

Berdasarkan kacamata kebudayaan, eksistensi Majelis Ulama Indonesia dan Pondok Pesantren, sebagai contoh kasus, adalah khazanah kultural sangat berharga yang pernah dimiliki oleh umat muslim Indonesia. Ketika fenomena sosial, politik, ekonomi, dan kebudayaan umat muslim dihadapkan pada problem berat yang menuntut pemecahan hukum maka lembaga-lembaga tersebut dapat hadir menjadi problem-solver. Apalagi ada budaya populer yang indikatorindikatornya dapat dilihat dari mediamedia sosial, dimana tokoh-tokoh masyarakat atau agamawan-agamawan muda dapat dengan gampang memberi fatwa hukum untuk menjawab persoalanpersoalan hidup yang diajukan umat. Semua ini adalah bukti bahwa masyarakat Indonesia sangat menerima model Islam progresif yang selalu mampu menjawab tantangan jaman.

Tanpa ada tujuan untuk menafikan atau mengeliminir peran dan fungsi lembaga-lembaga ijtihad yang sudah ada, tulisan ini coba menawarkan potensi lain yang selama ini tidak dilirik. Perguruan Tinggi Islam di Indonesia, di tengahtengah kultur masyarakat yang terbuka, adalah potensi besar yang dapat dikembangkan menjadi lembaga ijtihad. Sebagaimana Pondok Pesantren yang selain berperan sebagai lembaga pendidikan juga berperan sebagai lembaga yang punya otoritas mengeluarkan fatwa hukum, Perguruan Tinggi Islam pun dapat memainan peran gandanya; lembaga pendidikan dan ijtihad. Sebagaimana Majelis Ulama Indonesia yang memiliki legalitas hukum dari negara untuk menjalankan fungsinya, Perguruan Tinggi Islam juga memiliki payung hukum untuk menjalankan fungsinya. Hanya saja sampai saat ini Perguruan Tinggi Islam belum dilirik sebagai potensi besar untuk menjadi lembaga ijtihad.

Pendekatan yang dilakukan dalam tulisan ini pendekatan sosiologis, yang berguna untuk memotret persoalan sosial, terlebih dunia kampus, kemampuan intelektual dan potensi-potensi yang dimiliki. Dengan pendekatan sosiologis ini maka dapat ditemukan perbandingan, baik dimensi idenya maupun dimensi fisiknya. Jadi, pendekatan sosiologis membantu penulis untuk memahami aspek-aspek sosial yang meyakinkan untuk dijadikan modal sosial dalam membangun kemungkinan di masa depan, yaitu tepatnya menjadikan kampus 
sebagai lembaga formal yang bertugas tidak hanya dunia pendidikan melainkan jugamemberi kontribusi hukum Islam untuk kepentingan umat.

Sedangkan teori yang digunakan sebagai pisau analisa tulisan ini adalah teori konstruksi sosial. Istilah konstruksi sosial atas realitas (social construction of reality) didefinisikan sebagai proses sosial melalui tindakan dan interaksi dimana individu menciptakan secara terusmenerus suatu realitas yang dimiliki dan dialami bersama secara subyektif (Margareth Poloma, 2004). Realitas kampus adalah realitas akademik, yang selama ini mengusung satu identitas tunggal, yaitu sebagai lembaga pendidikan. Tetapi, realitas tunggal ini bisa dibedah menjadi identitas majemuk, salah satunya tidak menutup kemungkinan menjadi lembaga ijtihad jama'i.

Asal usul konstruksi sosial dari filsafat Kontruktivisme yang dimulai dari gagasan-gagasan konstruktif kognitif. Pengertian konstruktif kognitif muncul dalam tulisan Mark Baldwin, Jean Piaget, bahkan bisa ditelusuri sampai ke pemikiran Giambatissta Vico (Suparno, 1997). Semua pemikiran tokoh ini satu nada, yaitu bahwa gagasan yang terdapat dalam kesadaran manusia dapat diterjemahkan menjadi wujud yang konkrit, empiris, faktual, dan bisa diukur dengan standar realitas sosial. Sejatinya, hal ini mirip dengan pemikiran yang muncul sejak Socrates menemukan jiwa dalam tubuh manusia, sejak Plato menemukan akal budi dan ide (Bertens, 1999).

Gagasan tersebut semakin lebih konkret lagi setelah Aristoteles mengenalkan istilah, informasi, relasi, individu, subtansi, materi, esensi, dan sebagainya. Ia mengatakan bahwa, manusia adalah makhluk sosial, setiap pernyataan harus dibuktikan kebenarannya, bahwa kunci pengetahuan adalah fakta (Bertens, 1999). Fakta yang ada di luar diri manusia dapat membentuk pengetahuan yang terdapat dalam kognitif manusia, dan pemikiran kognitif dapat kembali menjelma menjadi realitas faktual di luar.

Konstruksi sosial merupakan sebuah teori sosiologi kontemporer yang dicetuskan oleh Peter L.Berger dan Thomas Luckman. Dalam menjelaskan paradigma konstruktivis, realitas sosial merupakan konstruksi sosial yang diciptakan oleh individu (Sukidin \& Basrowi, 2002). Dalam konteks penelitian ini, realitas sosial, dimana lembaga kampus dapat diubah menjadi lembaga ijtihad adalah hal yang masuk akal. Faktafakta yang berupa potensi-potensi yang dimiliki kampus dapat menjadi bahan reflektif untuk menyatakan bahwa kampus sangat berguna apabial dikontruk menjadi realitas baru, yaitu lembaga ijtihad atau memainkan dirinya sebagai lembaga ijtihad (Esposito, 1999).

Sosiologi pengetahuan Berger ini memusatkan pada dunia akal sehat (common sense). Berpikir secara "kontradiksi" dan "dialektis" (tesis, antitesis, sintesis) adalah hal niscaya. Sosiologi diharuskan memiliki kemampuan mensintesiskan gejala-gejala sosial yang kelihatan kontradiksi dalam suatu sistem interpretasi yang sistematis, ilmiah dan meyakinkan (Luckman, 1990).Dengan begitu, kita dapat memahami bahwa ksistensi lembaga kampus/perguruan tinggi sebagai lembaga pendidikan tidak bisa stagnan sampai di situ saja. Melalui proses kajian yang mendalam dan renungan yang kritisdialektis, potensi lain perguruan tinggi masih bisa digarap.

Ketika Berger dan Luckmann berpandangan bahwa kenyataan itu dibangun secara sosial, makak kita dapat membangun identitas baru untuk menambahkannya kepada institusi lama dengan identitasnya yang sudah usang. Realitas sosial baru ini tetap selalu menunggu kemauan dan usaha manusia untuk dilahirkan. Karenanya, dalam pandangan sosiologi, pengetahuan harus menganalisi proses terjadinya itu, dan 
tulisan ini akan menganalisa proses yang dibutuhkan, spirit-spirit yang diperlukan, untuk menciptakan atau mengkonstruk realitas sosial. Dalam teori konstruksi sosial ini, individu-individu dalam masyarakat mampu membangun masyarakat. Waters mengatakan bahwa manusia membangun kenyataan sosial di mana proses hubungan dapat menjadi tujuan yang pantas. Inilah inti pemikiran yang mendasari lahirnya teori sosiologi kontemporer; kosntruksi sosial (Sukidin \& Basrowi, 2002).

\section{PEMBAHASAN}

\section{A. Memahami Konteks Ijtihad}

Sebelum melangkah lebih jauh membahas potensi besar perguruan tinggi (kampus) sebagai lembaga formal untuk melaksanakan ijtihad jama'i, terlebih dahulu kita bahas tentang terminologi Ijtihad dalam tradisi intelektualisme Islam. Ijtihad berkaitan erat dengan persoalan hukum, terlebih hukum Islam, dan Ijtihad itu sendiri adalah proses kerja akademiknya, sedangkan hukum merupakan produk. Lazimnya, ijtihad dilakukan oleh ulama/intelektual tatkala hukum nash alQuran maupun Sunnah tidak secara eksplisit menjelaskannya (AshShiddieqy, 1999).

Dalam literatur keilmuan Islam, misalnya pendapat yang disampaikan oleh Imam Al-Ghazali, mendefinisikan ijtihad sebagai usaha serius dari seorang mujtahid dalam rangka merumuskan persoalan hukum syari'ah. Sebagian pendapat, sekalipun banyak yang menolak, mengatakan bahwa ijtihad itu adalah qiyas. Alasan penolakan, ijtihad lebih umum daripada qiyas. Imam Syafi'i sendiri menyebutkan bahwa arti sempit qiyas adalah ijtihad (Islam, 1986). Definisi lain tentang ijtihad datang dari pakar disiplin Ushul Fiqh, yaitu pencurahan tenaga dan pikiran dengan maksimal oleh seorang mujtahid untuk mendapatkan zann (asumsi awal) tentang hukum syar'I (Hosen, 2003).
Apapun definisi ijtihad di atas, terdapat beberapa hal yang bisa dicatat. Pertama, Ijtihad adalah suatu aktifitas serius, kritis, mendalam, radikal. Seorang mujtahid atau orang yang melakukan ijtihad pasti mencurahkan banyak tenaga dan pikiran, menggunakan seluruh pengetahuannya, untuk menggapai tujuan. Kedua, Ijtihad berkaitan dengan hukum syariah atau agama. Klausul ini mempersempit makna yang awal. Jadi, usaha atau kerja keras yang dicurahkan seseorang, namun tidak berkaitan dengan hukum Islam, maka tidak disebut Ijtihad. Sebaliknya, Ijtihad mensyaratkan kerja keras yang digunakan untuk menggali hukum Islam.

Kerja keras tersebut dapat dibreakdwon menjadi beberapa prasyarat yang harus dipenuhi seseorang untuk menjadi seorang mujtahid. Beberapa persyaratan tersebut menunjang kematangan nalar berpikir sekaligus kecakapan intelektualitasnya, seperti: baligh, berakal, berbakat dengan kemampuan nalar kritis, beriman, memahami Bahasa Arab, menguasai Usul Fiqih, mamahami Al-Qur'an dan Sunnah, memahami tujuan-tujuan hukum (almaqashid asy-syar'iyah), mengetahui dalil-dalil qath' $i$ terkait persoalan yang dikaji, dan mengetahui persoalanpersoalan perbedaan pendapat ulama, bertakwa kepada Allah dan beriman baik (Badriyah, As'ari, \& Susanto, 2017).

Syarat-syarat di atas dibuat oleh para ulama untuk tujuan memastikan kemampuan dan bakat seseorang yang hendak menjadi seorang mujtahid. Standarnya bisa saja dari aspek mentalitas, seperti batas usia dan umum, kecakapan intelektualitas, seperti beberapa disiplin ilmu yang harus dikuasai, maupun spiritualitas, seperti tingkat ketakwaan dan kesolehan. Mentalitas, intelektualitas, dan spiritualitas ini adalah tiga paradigma yang digunakan untuk merumuskan syarat-syarat seorang mujtahid.

Apabial seorang individu muslim memiliki syarat-syarat yang disebutkan di 
atas maka ia berhak untuk melakukan ijtihad. Bahkan, hukum melakukan ijtihad dapat dipetakan berdasarkan beberapa kategori sebagai berikut. Pertama, hukum ijtihad menjadi fardhu 'ain apabila ia ditanya soal perkara hukum, sementara orang/umat yang bertanya tidak menemukan seorang Qadhi lain untuk dimintai penjelasannya. Dalam kondisi semacam itu maka ijtihad menjadi fardu ain. Hukum ini sangat dominan dalam konteks har ini, mengingat persoalan umat semakin kompleks dan jarang bisa dijawab menggunakan rujukan-rujukan hukum yang sudah diformulasikan oleh ulama. Otomatis, demi menjawab kebutuhan umat akan hukum Islam maka ijtihad harus diwajibkan, terlebih bagi orang-orang yang memenuhi standar kapabilitasnya.

Kedua, fardhu kifayah, yaitutatkala persoalan hukum harus dijawab namun masih ada seorang Qadhi hukum lain yang bisa dimintai pertanggungjawabannya. Hal semacam ini bisa saja terjadi mengingat aspek kehidupan umat yang butuh akan jawaban hukum sangat kompleks, sehingga nyaris tidak satu orang pun yang mampu menguasainya. Sebaliknya, sering kal dijumpai seorang ulama hanya pakar di satu persoalan saja dan tidak pakar di persoalan lain. Jadi, umat yang bertanya pada seorang Qadhi dan kebetulan ia bukan pakarnya di bidang itu maka sang Qadhi bisa merekomendasikan umat tesebut kepada Qadhi lain yang lebih pakar. Di sini, hukum ijtihad bagi Qadhi pertama adalah fardhu kifayah.

Ketiga, Sunnah, yakni melakukan ijtihad untuk menjawab persoalan hukum dan peristiwa hukum tersebut belum terjadi. Jadi, apabila ada seorang muslim yang bertanya sebuah hukum demi tujuan antisipasi peristiwa hukum bakal terjadi di masa depan, maka melakukan ijtihad untuk menentukan hukum bagi peristiwa yang mungkin terjadi di masa depan adalah sunnah (Amiruddin, 2009).
Terakhir, hukum ijtihad adalah haram, yaitu melakukan ijtihad untuk mengubah hukum yang sudah tegas dengan adanya dalil-dalil qath' $i$, baik berupa ayat al-Quran maupun hadits Nabi. Atau juga, ijtihad yang dilakukan demi menyalahi ijma ulama bisa berhukum haram. Selain itu, ijtihad yang dilakukan oleh orang-orang yang tidak memenuhi syarat menjadi mujtahid juga haram. Sebab, kemungkinan terbesarnya adalah produk hukum yang menyesatkan umat. Kita bisa membayangkan, seseorang yang mengeluarkan fatwa hukum tentang ekonomi Islam, padahal dirinya tidak dibekali pengetahuan dan disiplin ilmu ekonomi yang mendalam. Tentu saja, fatwa hukumnya tidak ilmiah (Shidiq, 2011).

Beberapa syarat penting menjadi seorang mujtahid seperti di atas itu sangat dibutuhkan dan perlu diperhatikan. Sebab, seiring perjalanan waktu, terlebih setelah Rasulullah saw wafat, ijtihad semakin diperlukan oleh para ulama mujtahid. Mereka dituntut mamampu menjawab berbagai persoalan hukum. Umat muslim semakin luas, tinggal di berbagai kawasan, dan hidup dari generasi ke generasi. Tentu saja, seiring dengan itu semua, permasalahan baru timbul. Ijtihad yang tetap berpegang kepada prinsipprinsip Islam yang terkandung dalam AlQur'an dan Hadtis sangatlah diperlukan (Shidiq, 2011).

Secara simbolik, ijtihad adalah upaya umat muslim untuk tetap memperjuangkan eksistensi Islam sebagai agama yang universal dan cocok dengan segala jaman. Melalui pintu ijtihad, hukum Islam dapat masuk ke setiap detain kehidupan sehari-hari umat manusia, mulai dari urusan domestik sampai urusan kebangsaan dan kenegaraan. Melalui pintu ijtihad pula, Islam bisa diterima oleh umatnya yang memiliki identitas kultural yang berbeda, baik yang di Asia, Eropa, Amerika, Afrika maupun benua lainnya. Ijtihad adalah ajaran Islam, sebab Allah swt dan Rasulullah saw selalu meminta 
umatnya untuk berpikir, menyelesaikan persoalan hidup mereka sendiri (Hasan, 1984).

Kompleksitas persoalan hidup dalam sejarah manusia itulah mendorong pentingnya melakukan ijtihad. Tentu saja, ijtihad yang mencerahkan, memberi solusi, menyelesaikan persoalan, bukan ijtihad yang merusak, destruktif, dan memecah belah persatuan. Tidak jarang sebagian ulama mengeluarkan fatwa tanpa berpikir panjang konsekuensi dari fatwanya, bahkan sedari awal telah berupaya untuk menghancurkan umat muslim dari dalam sendiri. Karenanya, ijtihad dilakukan untuk menjawab kompelsitas umat, yang jawabannya belum pernah ada sebelumnya (Shidiq, 2011).

Umat Islam sudah mengenal bahwa shalat, zakat, haji, puasa adalah perkaraperkara wajib yang harus dilakukan oleh umat Islam. Tetapi, bagaimana dengan persoalan program Keluarga Berencara (KB), pembuatan bayi tabung di laboratorium kedokteran, bunga perbankan dan contoh lainnya, sementara semua problem baru tersebut memiliki pertimbangan kontekstualnya tersendiri. Di sinilah, signifikansi ijtihad menemukan momentumnya (Islam, 1986). Sekali lagi perlu ditegaskan bahwa ijtihad berlaku pada ayat atau hadis yang bersifat zhan bukan qath'i. Dalam al-Quran kita mengenal ayat-ayat mutasyabihat dan muhkamat. Ada beberapa perintah agama yang sudah terang benderang, tetapi ada juga yang masih samar-samar. Ranah ijtihad adalah menjelaskan apa yang masih buram. Lebih-lebih apabila menemukan permasalahan yang hukumnya belum ada dalam nash maka otomatis ijtihad diperlukan. Jadi, ijtihad tidak berlaku pada masalah yang hukumnya sudah pasti (qath'i). Mengeluarkan zakat hukum adalah wajib, mengerjakan shalat lima waktu juga wajib, begitupun puasa dan haji semua wajib. Ijtihad tidak dilakukan untuk merubah hukum yang sudah jelas seperti ini (Shidiq, 2011). Namun, apabila ada persoalan hukum yang belum jelas maka Islam harus mampu menjawabnya dan harus tetap aktual. Hukum Islam harus tampil dalam wajah baru, dan hal itu bisa ditempuh dengan cara melakukan reformasi atau tajdid figh. Dalil-dalil syara' yang menjadi rujukan ulama mujtahidin terdahulu dipelajari, dikiritsi, dan direvisi sekiranya dibutuhkan. Kemudian, perkembangan situasi dan kondisi historis masa sekarang menjadi bahan pertimbangan. Hukum baru bisa diputuskan dan ditetapkan apabila semua proses ilmiah rasional argumentatif dilakukan oleh mujtahid (Amiruddin, 2009). Apabila terjadi perbedaan pendapat yang dilakukan oleh para mujtahid, apabila umat menemukan berbagai jawaban yang variatif dari fuqaha maka ikhtilaf semacam ini merupakan kekayaan fiqh yang besar, patut disyukuri, dihargai, tanpa harus dipertentangkan satu sama lain. Perbedaan menjadi rahmat dan anugerah. Umat muslim dapat memilih mana saja pandangan hukum yang paling tetap dan kontekstual dengan kehidupan pribadi masing-masing. Adalah lazim apabila produk pemikiran mujtahid berbeda-beda karena kemampuan masingmasing mujtahid pun berbeda (AshShiddieqy, 1999).

Dalam literatur intelektual Islam, kita mengenal beberapa kategori mujtahid. Pertama, mujtahid fi al-syar'i, yaitu suatu label yang dilekatkan kepada mujtahid mustaqil. Orang-orang yang mendapat gelar mujtahid mustaqil adalah ulama yang sudah pakar dalam bidang hukum dan aspek-aspek keilmuan lainnya, sehingga mereka mampu membangun suatu madzab pemikiran sendiri, seperti Imam Abu Hanifah, Imam Malik bin Anas, Imam Muhammad bin Idris asySyafi'i, dan Imam Ahmad bin Hambal. Empat orang ini disebut mujtahid mustaqil, orang-orang yang sudah independen dan mandiri dalam menentukan hukum Islam. 
Kedua, kategori mujtahid $f i$ almazhab, yaitu para ulama yang mampu membangun pemikiran sendiri namun tetap berada dalam satu madzab besar. kita bisa menyebut orang-orang seperti Abu Al-Hasan Kharkhi (260-340 H), Abu Ja'far At-Thahawi (230-321 H), dan AlHasan bin Ziyad (wafat $204 \mathrm{H}$ ) dari kalangan Hanafiyah, Muhammad bin Abdullah Al-Abhari (289-375 H) dari kalangan Malikiyah, dan Ibnu Abi Hamid Al-Asfrini (344-406 H) dari kalangan Syafi'iyah.

Ketiga, kategori mujtahid fi almasa'il, yaitu orang-orang yang melakukan ijtihad untuk menemukan rumusan hukum dalam beberapa hal hukum, tidak tentang keseluruhan bangunan hukum, apalagi sampai membahas hukum-hukum yang besar. Mujtahid Fi Al-Masa'il ini membahas masalah-masalah spesifik dan bukan yang umum. Imam Al-Thahawi dari kalangan Hanafiyah, Al-Ghazali dari kalangan Syafi'iyah, dan Al-Khiraqi dari kalangan Hanabilah adalah contoh ulama-ulama yang masuk kategori mujtahid $f i$ almasail.

Keempat, mujtahid muqoyyad, yaitu seorang mujtahid yang mengikat pendapatnya sendiri dengan pendapat ulama salaf dan mengikuti cara ijtihad mereka. Ketika menghadapi suatu persoalan hukum, misalnya, seorang mujtahid muqoyyid mencontoh gaya-gaya dan metode-metode yang dilakukan oleh ulama madzhab yang diidolakannya. Ada banyak ulama yang melakukan pola ijtihad semacam ini, seperti Imam AthThahawi, Al-Kurkhi, dan As-Sarkhasi (Mazhab Hanafi), Al-Abhari dan Ibnu Abi Zaid Al-Qairuwani (Mazhab Maliki), Abu Ishaq Asy-Syirazi, Ibnu Khuzaimah, dan Muhammad bin Jarir (Mazhab Syafi'i), Al-Qadhi Abu Ya'la dan Al-Qadhi Abu Ali bin Abu Musa (Mazhab Hambali) (Sapiudin Shidiq, 2011: 257-259).

Semua kategori di atas sejatinya bertujuan untuk memetakan batas kemampuan seseorang dalam melakukan ijtihad. Karena sebagian merasa tidak memiliki kapasitas keilmuan seperti yang dimiliki oleh orang lain, maka ia membatasi dirinya dalam melakukan ijtihad sesuai kemampuan dan intelektualitasnya sendiri. Dari sanalah, banyak para ulama yang berbeda-beda dalam melakukan ijtihad, sesuai kategorinya masing-masing. Dilihat dari aspek lain, yaitu model ijtihadnya, AdDuwalibi memiliki kategori sendiri. Bagi Ad-Duwalibi ada tiga macam ijtihad.

Pertama, Ijtihad Bayani, yaitu menjelaskan hukum-hukum syariat berdasarkan teks nash-nash syar'i. Ijtihad model ini merupakan metode ijtihad yang lebih menitikberatkan kepada kajian kebahasaan/linguistik. Dengan cara ini, ulama ingin menjelaskan tentang batasanbatasan yang bisa dipikirkan terkait teks suci. Melalui kajian linguistik semacam itu pula, nash qath'i dan zhanni bibedakan, status ketarjihan dan sasaran teks bisa ditentukan. Kata Bayani itu sendiri merujuk pada teks yang dibatasi, diberi ruang lingkup, sesuai dengan tujuan Syari' (pembuat teks, Tuhan).

Kedua, Ijtihad Qiyasi, yaitu memberlakukan hukum-hukum syari'ah untuk peristwa-peristiwa berbeda yang penejelasan tegasnya tidak terdapat di dalam al-Quran maupun as-Sunnah. Jalan yang digunakan adalah metode qiyas. Muhammad Salam Madkur mengatakan ijtihad qiyasi adalah upaya mujtahid untuk memutuskan hukum yang belum dijelaskan oleh nash qathi' maupun zhanni, juga tidak ada pendapat ijma' mengenainya. Kemudian, mujtahid yang bersangkutan tiba pada satu kesimpulan hukum dengan memperhatikan indikatorindikator yang telah ada, menemukan kemiripan antara peristiwa yang ditegaskan dalam al-Quran dan peristiwa yang hendak dicari ketetapan hukumnya.

Ketiga, Ijtihad Ishthishlahi, definisi model ketiga ini sama dengan ijtihad model kedua, hanya saja, bila model kedua menggunakan metode Qiyas maka model ketiga menggunakan logika (ar- 
$\left.r a^{\prime} y u\right)$. Penggunaan logika disini bisanya disandarkan pada kemaslahatan umat (ishtishlah). Ijtihad ini merujuk kepada kaidah jalb al-mashlahah wa daf' almafasid (meraih kemaslahatan dan menghindari keburukan), sesuai dengan aturan yang telah ditetapkan agama (AshShiddieqy, 1999).

Beberapa ulama dengan beragam tingkatannya di atas dapat melakukan beberapa tipe model ijtihad sesuai tiga kategori tersebut (bayani, qiyasi, ishthilahi). Tentu saja, pertimbangan utamanya adalah kecenderungan subjektifnya, pilihan objektifnya, kapabilitas dan kapasitas keilmuannya, serta arah dan tujuan dari risetnya. Semua hal itu dapat dilakukan dengan kerja-kerja akademik yang ilmiah, rasional, logis, sesuai standard-standard disiplin ilmu pengetahuan yang ada. Semakin berkembang ilmu pengetahuan maka semakin banyak aspek ilmiah yang perlu dipertimbangkan oleh seorang mujtahid, baik memiliki tipe ijtihad bayani, qiyasi maupun isthilahi.

\section{B. Perguruan Tinggi Sebagai Lembaga Ijtihad Jama'i}

Perguruan Tinggi mulai tingkat sekota tinggi, institut sampai universitas adalah lembaga formal yang mengajarkan berbagai disiplin ilmu pengetahuan, mulai dari agama, sains, sampai sosial. Di lembaga ini peserta didik diajari menjadi pakar dalam bidang masing-masing. Lebih dari itu, mahasiswa (sebutan untuk orangorang yang berproses di perguruan tinggi) juga melakukan riset ilmiah untuk mengembangkan ilmu pengetahuan, merevisi rumusan-rumusan teoritis konseptual yang ada, dan berkontribusi besar bagi kepentingan umat manusia dalam seluruh aspek hidupan.

Mahasiswa dan Dosen di perguruan tinggi mengamini bahwa Al-Quran dan Hadits adalah firman suci Allah swt dan rasul-Nya yang tidak bisa diubah, dikurangi ataupun ditambah. Sedangkan ijtihad adalah proses interpretasi terhadap sumber hukum Islam yang dapat berkembang seiring waktu dan perbedaan tempat (Kamali, 1991). Tetapi, mahasiswa dan dosen terus mengkaji dan menempatkan pemikiran Islam sebagai produk pemikiran manusia yang profan, produk ijithad yang sewaktu-waktu butuh kontekstualisasi dengan tuntutan jaman. Oleh karenanya, lembaga perguruan tinggi memotivasi terus-menerus proses penelitian ilmiah, terlebih terkait hukumhukum keagamaan.

Apabila para ulama seperti AlAmidi (w. 1233 M.) dan Al-Baidawi (w. 1286 M.) mengatakan bahwa ada dua syarat utama untuk menjadi seorang mujtahid, pertama, seorang mujtahid harus memiliki keimanan yang kuat terhadap Allah swt dan Rasulullah saw, dan kedua, seorang mujtahid harus memiliki kecakapan intelektual dalam berbagai aspek dan disiplin ilmu pengetahuan. Lembaga perguruan tinggi telah memenuhi kedua syarat tersebut. Dengan kata lain, jika definisi dari mujtahid kolektif adalah kumpulan pakar hukum yang berijtihad bersama untuk menetapkan hukum Islam, maka peluang dan potensi perguruan tinggi untuk menjadi lembaga ijtihad kolektif terbuka lebar (Al-Amidi, n.d.) Para intelektual yang berkader di perguruan tinggi sangat menyadari betul bahwa banyaknya problem yang dihadapi oleh masyarakat modern, banyaknya pemikir islam dari berbagai disiplin keilmuan, menuntut dirinya untuk terus berkarya demi umat. Di sinilah peran perguruan tinggi sejalan dengan pemikiran Yusuf al-Qardawi yang mengatakan bahwa model ijtihad yang paling tepat sekarang ini adalah ijtihad jama'i (Al-Qardawi, 1984). Kaum akdemikus kampus adalah sekumpulan intelektual dengan bekal disiplin ilmu pengetahuan yang komplit, mulai dari sains eksakta, sains sosial, sampai disiplin-disiplin ilmu keagamaan.

Bahkan, jika standar untuk mengangkat kampus sebagai lembaga ijtihad jama'i harus mengikuti pandangan Imam Al- 
Ghazali, yang mengatakan bahwa seorang mujtahid harus menguasai ilmu hadits, ilmu lughah, dan ushul fiqih, maka syaratsyarat tersebut pun sudah terpenuh (AlGhazali, n.d.). Di dalam perguruan tinggi (atau akrab disebut kampus) telah dipelajari dengan kritis, ilmiah, rasional serta mendalam berbagai ilmu-ilmu tersebut. Fakultas-fakultas seperti sastra dan budaya, ushuluddin, bahkan perbandingan agama adalah instrumeninstrumen yang dimiliki kampus untuk memenuhi prasyarat yang ditetapkan ulama salaf tentang standar siapa yang berhak melakukan ijtihad.

Pada suatu hari Ali bin Abi Thalib bertanya kepada Rasulullah saw., "wahai Nabi, bagaimana jika ada satu persoalan di antara kita, sedangkan tidak ada wahyu maupun sunnah yang menjawabnya?" Nabi menjawab, "Kamu harus menemui para ulama, dan berkonsultasi pada mereka. Jangan membuat keputusan hanya berdasar satu pendapat" (Uwes, n.d.). Hadits ini dapat dijadikan legitimasi hukum syar'i yang membolehkan lembaga kampus/perguruan tinggi untuk menjadi lembaga ijtihad. Seminar-seminar akademik adalah representasi dari pemenuhan konsultasi hukum yang disarankan oleh Nabi dalam sabdanya.

Secara substantif, ijtihad jama'i adalah kerja ilmiah yang dilakukan oleh para pakar dan intelektual yang bekerja bersama-sama untuk memecahkan persoalan umat manusia. Gagasan semacam ini sejatinya telah ada dalam sejarah Islam. Kita lihat bahwa penggunaan istilah ijtihad jama'i ini sama halnya dengan merujuk pada konsep ijma' ulama (kesepakatan para ulama). Mahmud Syaltur sendiri menggunakannya pada tahun 1950-an untuk menjelaskan tentang konsep Ijma' Ulama (Syaltut, 1988). Antara Ijma' ulama dan ijtihad jama'i adalah serupa secara substansial, dimana ada banyak individu yang mengeluarkan pendapat untuk mencapai satu kesepahaman hukum.
Untuk menjadikan perguruan tinggi sebagai lembaga ijtihad jama'i, yang kelak dapat dijadikan rujukan hukum oleh umat dan publik (termasuk pemerintah), hanya membutuhkan kesiapan dari kalangan internal kampus itu sendiri dan serta pengakuan dari masyarakat/umat muslim, formil maupun non-formil. Sebab, pada tahun 1964, berbagai intelektual muslim dari seluruh penjuru dunia pernah berkumpul untuk menghadiri sebuah muktamar yang diselenggarakan oleh Majma' Buhuts Islamiyah di Kairo. Sejak saat itulah, diperkanlan satu konsep yang dikenal dengan sebutah ijtihad jama'i atau ijtihad kolektif. Terminologi itupun menjadi terminologi yang menyebar ke seluruh dunia ('Uf, 1982).

Dalam muktamar di Kairo itu, diputuskan beberapa point penting sebagai berikut. Pertama, Al-Quran dan Hadits adalah sumber hukum Islam yang final, sedangkan Ijtihad dapat dilakukan oleh orang-orang yang telah memenuhi berbagai persyaratan yang dibutuhkan. Kedua, prosedur yang harus ditempuh untuk menjaga maslahah dan memecahkan problem umat adalah mengambil hukum dari sekolah-sekolah Islam, jika solusi ini tidak juga membuahkan hasil maka ijtihad jama'i madzhabi (kolektif dalam satu perspektif madzhab) dapat dilakukan ijtihad jama'i mutlak. Ketiga, institusi Majma' Buhuts Islamiyah ini berperan untuk mengorganisir dua kategori ijtihad jama'i tersebut (Al-Taujih al-Tasyri'i fi al-Islam min Buhus Mu'tamarat Majma' al-Buhus al-Islamiyah, Vol. 2, 1972). Poin-poin yang dideklarasikan oleh Majma' Buhuts Islamiyah di atas, sejatinya, adalah jawaban yang tegas bahwa perguruan tinggi atua kampus memiliki hak untuk menjadi lembaga ijtihad. Di dunia kampus terdapat keyakinan final bahwa al-Quran dan Sunnah adalah firman suci yang berdasarkan wahyu, tidak bisa diotak-atik, sakral, dan sudah final. Sedangkan keyakinan bahwa produk pemikiran hukum Islam tetaplah ciptaan manusia 
yang selalu terbuka untuk mendapat kritik, revisi, dan perubahan. Kesadaran kritis semacam itu sudah tidak bisa dipertanyakan lagi di kalangan akademikus kampus.

Mengapa penting mengangkat isu bahwa kampus atau perguruan tinggi segera mendeklarasikan dirinya sebagai lembaga ijtihad, salah satu pertimbangannya adalah bahwa sekalipun institusi Majma' Buhuts Islamiyah ini menyatakan akan mengorganisir proses dialektika ijtihad jama'i di seluruh dunia, tetapi dalam prakteknya, hal itu tidak berjalan mulus. Kini sudah tiba saatnya menunjukkan kepada dunia Islam bahwa perguruan tinggi Islam di Indonesia siap menjalankan amanat Majma' Buhuts Islamiyah tersebut, siap merespon semua tantangan jaman dan kebutuhannya, dan di samping itu, siap menggalang dukungan publik Nusantara untuk mendukung citacita Islam progresif yang ditelurkan dari dunia intelektual kampus.

\section{Berbekal Sejarah dan Spirit Dunia}

Seperti yang sudah dibahas di pendahuluan, tradisi dan budaya di Indonesia sudah membuktikan. Ijtihad Jama'i telah mengakar sampai ke lembaga-lembaga seperti pesantren, lingkaran-lingkaran diskusi Bahtsul Masail di Tradisi Nahdhatul Ulama maupun Majelis Tarjih ala Muhammadiyah. Kultur masyarakat muslim Indonesia merupakan background sosial yang sangat berharga untuk membangun suatu lembaga perguruan tinggi yang turut serta dalam menjadikan dirinya sebagai salah satu lembaga Ijtihad Jama'i.

Di dalam sejarah intelektual muslim Indonesia, kita melihat adanya spirit rasionalisme ilmiah yang sama, yaitu ketika, salah satunya, K.H. Hasyim Asy’ari mengatakan, “jika engkau melihat para ulama dan tidak setuju dengan pemikiran mereka, maka jangan pernah menghina mereka. Berilah mereka nasehat dengan baik. Jika tetap saja mereka tidak mengikuti seruanmu maka tetap jaga sikap dan jangan mencemooh. Jika engkau mencemooh maka hal itu ibarat engkau ingin membangun istana tapi lebih dulu menghancurkan kota" (Noer, 1973).

Pandangan Kiai Hasyim ini, pendiri Ormas Nahdhatul Ulama, adalah spirit radikal intelektualisme, dimana pandangan-pandangan ilmu pengetahuan tetap harus dihargai demi membangun ilmu pengetahuan yang baru. Logika ilmu pengetahuan, baik eksakta maupun sosial, juga bekerja seperti itu. Rumusanrumusan teoritis dan konseptual dari seorang ilmuan tetaplah dihargai oleh ilmuan berikutnya yang menemukan rumusan konseptual-teoritis baru. Sebab, penemuan sebelumnya adalah basis pijakan untuk penemuan berikutnya. Hanya saja, K.H. Hasyim Asy'ari menyampaikan hal tersebut dalam konteks etika. Padahal juga berlaku dalam dunia sains. Misalnya, ketika Newton mengatakan bahwa gravitasi adalah sebuah energi dan ilmuan berikutnya seperti Einstein mengatakannya sebagai sebuah konsekuensi dari massa dan ruang maka tidak satupun intelektual yang mencelah pemikiran intelektual lainnya, sebab dari situlah sejarah perkembangan ilmu pengetahuan dibangun.

Dalam konteks pemikiran keislaman di Indonesia, gerakan untuk melakukan revisi metodologis sudah berkembang sejak awal abad 20. Perkembangan ini adalah khazah histrois yang sejatinya bisa digunakan untuk menumbuhkan rasa percaya diri bagi dunia kampus, terlebih untuk melangkah lebih jauh, tidak sekedar menjadi lembaga pendidikan melainkan juga lembaga Ijtihad. Kita tahu bahwa pada tahun 1988 di Pesantren Watucongol, Muntilan, Magelang, Jawa Tengah, para kiai berkumpul bersama mendiskusikan metode membaca kitab kuning dengan cara yang lebih kritis, memahami teks dan konteks sosialkulturalnya, supaya mereka mampu memahami teks secara kontekstual. Sebelumnya, teks (terlebih kitab kuning) 
masih dipahami secara literlek dan dilepaskan dari penafsiran terkait kapan dan dimana teks itu dibuat. Sehingga, ada bagian paling subtil yang tereduksi, yaitu spirit teks.

Diskusi berlanjut di tahun 1998 di Pesantren Krapyak, Yogyakarta, untuk membahas tentang bagaimana metode Bahtsul Masail yang tepat. Di tahun yang sama, di Pesantren Jombang, pertemuan ketiga diselenggarakan untuk menentukan metode membedakan antara mengutip pendapat ulama secara leterlek (qauli) dan metodologis (manhaji). Sejak saat itulah mulai dikenal istilah Fiqih Sosial yang tidak lagi membahas tentang hukum ritual melainkan ranah yang lebih luas, seperti persoalan militer, prostitusi, pajak, demokrasi dan semacamnya. Beberapa pertemuan ulama Nusantara itu menghasilkan kesimpulan bahwa tidak hanya kitab kuning yang dibutuhkan melainkan juga Qawaid Fiqhiyah dan Qawaid Ushuliyah. Dari sinilah, seluruh pakar ilmuan dari berbagai disiplin harus dimintai pendapatnya, seperti pakai ilmu sains, teknik, maupun ekonomi dan politik (NU, 1992).

Apa yang dilakukan oleh para ulama secara kultural ini merupakan bekal utama bagi kampus untuk mempelajari bahwa di dalam sejarah pemikiran Islam kita suah ada segolongan ulama yang bersama-sama memilikirkan Islam dengan cara-cara yang saintifik, ilmiah, rasional, dan metodologis. Jika kampus meyakini bahwa dirinya sendiri sebagai lembaga pendidikan yang mengajarkan tema-tema sains dengan metode-metode rasional empiris maka belajar kepada sejarah menjadi penting. Mengapa penting? Karena pola dan bentuk bagaimana ijtihad jama'i dilakukan telah ada contohnya. Jadi, dunia kampus tidak lagi perlu memikirkan format melainkan cukup melanjutkan tradisi akademik yang sudah berjalan.

Perubahan radikal dalam kultur akademik keislaman Nusantara ini ternyata juga diakui oleh para pemikiran asing, seperti Martin van Bruinessen yang mencatat perkembangan memuaskan itu. Menurutnya, intelektual Indonesia telah berhasil meraih perubahan fundamental, terlebih seperti apa yang dicontohkan oleh para ulama Nusantara itu. Marti van Bruinessen mendorong kita untuk berterimaksih kepada ulama-ulama senior seperti K.H Sahal Mahfudh dan Kiai Imron Hamzah bukan sekedar karena perubahan tema-tema yang dibahas dalam Bahtsul Masail melainkan juga karena perubahan pada metodologi yang para ulama gunakan dalam membahas persoalan umat (Bruinessen, 1996). Apa yang dihargai dan dikagumi oleh intelektual asing seharusnya menjadi perhatian penuh kita semua agar bangsa dan negara, terlebih dalam aspek intelektualitas, menjadi setara di mata dunia. Dunia Kampus sejatinya punya potensi besar untuk berperan mengangkat harkat martabat bangsa melalui perananannya di ranah intelektual, dalam konteks tulisan ini sebagai lembaga ijtihad jama'i. Jika peran dan identitas kampus dikembangkan ke ranah yang lebih luas, yang tidak sekedar berkutat pada status sebagai lembaga pendidikan, maka tentu saja pencapai besar dunia intelektualitas kita akan mengagumkan mata dunia. Benar apa yang dikatakan oleh K.H Husein Muhammad, dari Pesantren Arjawinangun, ia meyakini bahwa para ulama di Nusantara ini sudah memiliki kapabilitas untuk melakukan ijtihad sendiri hanya saja mereka terlalu rendah hati untuk mendeklarasikannya. Rasa percaya diri para ulama dapat diambil alih oleh perguruan tinggi kampus. Para ulama Nusantara telah memberi contoh dan terus-menerus mencoba untuk mengkompromikan sumber-sumber rujukan hukum mereka dan dengan penuh kehati-hatian menginterpretasikannya agar sesuai dengan konteks jaman. Sekarang giliran kampus mengambil alih spirit modernisme Islam tersebut. Sprit modernisme itu sendiri adalah berbagai upaya mencari jalan tengah antara 
adaptasi dan menolak; beradapatasi dengan perkembangan jaman dan warisan budaya, serta menolak hal-hal buruk baik yang diwariskan masa lalu maupun yang dibawa oleh masa kini (Esposito, 1999). Melalui berbagai disiplin ilmu pengetahuan yang diajarkan, dikembangkan, dan dikontribusikan oleh kampus maka lembaga ini tidak hanya mampu mengemban amanat menjadi bagian dari institusi penidikan formal melainan juga mampu menjadi lembaga ijtihad jama'i yang formal pula.

Selain historis-kultural yang sudah ada sebagai modal untuk membangun basis kepercayaan diri kampus untuk menjadi lembaga ijtihad jama'i secara formal, kampus juga bisa mengambil batu pijaknya pada spirit jaman. Untuk jaman kita sekarang, mendekati teks secara rasional, memenuhi tuntutan jaman, membuat Islam lebih dimengerti oleh semua orang, adalah tindakan paling penting, karenanya Ijtihad dibutuhkan. Umat manusia di dunia sekarang membutuhkan penjelasan rasional. Satusatunya cara untuk menjelaskan Islam secara rasional adalah melalui pintu ijtihad (Dar, 1957).

Cara rasional yang bisa ditempuh oleh umat muslim adalah mewartakan Islam melalui kacamata saintifik, yang salah satunya bisa dilakukan oleh perguruan tinggi kampus. Berbagai mata pelajaran dan disiplin ilmu pengetahuan yang dikemas dalam kurikulum perguruan tinggi adalah salah satu media yang bisa digunakan oleh pemikir Islam untuk menyampaikan Islam kepada dunia. Melalui media inilah, Islam lebih berpeluang untuk diterima, dimengerti, dan secara substansial sulit untuk diselewengkan. Sebaliknya, sering sekali Islam dikecam oleh dunia, terutama dunia Barat, karena paham keislaman mereka tidak "lulus sensor" dunia akademik kampus. Radikalisme dan fundamentalisme Islam itu adalah salah satu versi Islam yang tidak akan pernah diterima oleh logika rasional kampus, dan tidak akan diajarkan di dunia kampus. Sayyid Ahmad Khan mengatakan bahwa Islam sejalan dengan spirit rasionalisme dan intelektualisme (Christian W. Troll, 1978). Tentu saja, kampus bisa menjadi simbol Islam yang rasional.

Al-Quran surat An-Najm ayat 39-41 sebagai tuntutan Tuhan dan perintah-Nya agar umat muslim terus-menerus berubah dan mengembangkan potensi diri, sesuai dengan nilai-nilai humaniti. Untuk itulah, ayat ini menjadi pijakan legitimasi untuk melakukan Ijtihad yang tiada henti. Dahulu, Islam disampaikan dengan bentuk hukum (fiqih), filsafah (kalam), dan sufisme (tasawuf). Hari ini, Islam juga bisa disampaikan dalam bentuk atau format saintifik, sesuai dengan spirit modernitas (Al-Din, 1960). Melalui pintu ijtihad yang terus-menerus dilakukan maka Islam akan terus berkembang, dan dunia kampus menjadi rahim yang kelak melahirkan Islam rahmatan lil alamin, melalui karakteristiknya yang ilmiah, rasional, dan selaras dengan spirit jaman yang saintifik.

Dorongan untuk melahirkan Islam yang saintifik itu juga datang dari pemikir Islam, Muhammad Iqbal, ia merasakan betapa pentingnya kehadiran Islam dengan warna baru, yaitu Islam yang saintifik, sebagai bentuk jawaban terhadap modernitas yang telah datang menantang (Iqbal, 1936). Hanya dengan Islam Saintifik ini, Islam yang dilahirkan dari meja-meja diskusi kampus, maka dunia pasti akan tercengang, terlebih dengan model keislaman di Indonesia. Sebab, sedari awal, para intelektual Eropa telah mengakui bahwa di dunia Islam geliat pertumbuhan Islam Saintifik telah bertumbuh, terlebih di bumi Nusantara (Low, 1906).

\section{SIMPULAN}

Tulisan ini adalah refleksi awal untuk dikembangkan di kemudian hari, dengan penelitian/riset yang lebih mendalam, mengungkap potensi dan kesiapan dunia akademik perguruan tinggi 
untuk mengemban amanah yang lebih besar. Amanah itu datang bukan dari manusia melainkan dari spirit jaman yang telah berubah. Islam tidak hanya bergantung kepada orang-orang yang secara serius mendalami ilmu-ilmu agama semata melainkan juga kepada orangorang yang mempelajari ilmu-ilmu humaniora. Ilmu agama dan ilmu humaniora dapat dikolaborasikan, diintegrasikan, diinterkoneksikan, untuk melahirkan pemahaman yang lebih utuh tentang kehidupan.

Apabila secara prinsipil telah diterima, bahwa seluruh basis dan disiplin keilmuan dapat disatukan, maka upaya untuk mempersatukan lembaga-lembaga yang sifatnya fisik dan teknis tentu akan lebih mudah. Apabila visi dan misi telah sama maka program-program kerja untuk mewujudkannya lebih mudah digarap. Dalam konteks tulisan ini, lembaga fatwa keagamaan dan lembaga pendidikan kampus memiliki visi yang sama, yaitu memberikan penecerahan kepada umat manusia, menuntunnya ke jalan yang benar. Karenanya, otoritas untuk mengeluarkan fatwa tidak semata dipegang oleh mereka yang berada di jalur pendidikan agama murni melainkan juga ada hak orang-orang yang mendalami disiplin berbeda.

\section{DAFTAR PUSTAKA}

'Uf, A. M. (1982). Al-Azhar fi Alf `Am. Cairo: Majma' al-Buhus alIslamiyah.

Al-Amidi, S. al-D. (n.d.). Al-ihkam fi Usul al-Ahkam, Vol. 3, (Egypt: Matba'ah Syabih, 1347 H.), hlm. 139, lihat juga Abu Nur Zuhair, Muzakkirah fi Usul al-Fiqh li Ghair alAhnaf, Vol. 4. Egypt: Matba'ah Dar al-Ta'lif, t.t.

Al-Din, M. U. (1960). Sir Sayyid's New Mode of Religious Thought," dalam N. Quraishi, Aligarh Movement: From Emergence to Epitome. Aligarh: Aligarh Muslim University.
Al-Ghazali, A. H. M. (n.d.). Al-Mustasfa min 'Ilm al-Usul, Vol. 4 (Vol. 4). alMadinah al-Munawwarah: alJami'ah al-Islamiyah, t.t.

Al-Qardawi, Y. (1984). Al-Ijtihad wa alTajdid baina al-Dawabit al-

Syar'iyyah wa al-Hajat alMu'asirah," dalam al-`Ummah, Qatar, 31 May.

Al-Taujih al-Tasyri'i fi al-Islam min Buhus Mu'tamarat Majma' al-Buhus al-Islamiyah, Vol. 2. (1972). Cairo.

Amiruddin, Z. (2009). Ushul Fiqih. Jogjakarta: Teras.

Ash-Shiddieqy, T. M. H. (1999). Pengantar Ilmu Fiqh. Semarang: PT. Pustaka Rizki Putra.

Badriyah, L., As'ari, A. R., \& Susanto, H. (2017). Analisis Kesalahan Dan Scaffolding Siswa Berkemampuan Rendah Dalam Menyelesaikan Operasi Tambah dan Bilangan Bulat. Jurnal Pendidikan : Teori, Penelitian, Dan Pengembangan, 2(1).

Bertens, K. (1999). Sejarah Filsafat Yunani. Yogyakarta: Kanisius.

Bruinessen, M. van. (1996). Traditions for the Future: The Reconstruction of Traditionalist Discourse within NU," dalam Barton and Fealy (eds.), Ulama, Traditionalist Islam and Modernity in Indonesia. Monash Asia Institute: Monash University.

Christian W. Troll, S. A. K. (1978). A Reinterpretation of Muslim Theology. New Delhi: Vikas Publishing House.

Dar, B. A. (1957). Religious Thought of Sayyid Ahmad Khan, I st ed. Lahore: Instt of Islamic Culture.

Esposito, J. L. (1999). Contemporary Islam: Reformation or Revolution?", dalam John L. Esposito (Ed.), The Oxford History of Islam. New York: Oxford University Press.

Hasan, A. (1984). Pintu Ijtihad Sebelum Tertutup. 1984: PUSTAKA.

Hosen, I. (2003). Fiqh Perbandingan Masalah Perkawinan. Jakarta: 
Pustaka Firdaus.

Iqbal, A. M. (1936). Islam and Ahmadism.

Lahore: Anjuman-i- Khuddam ud

Din.

Islam, D. P. P. T. A. (1986). Ushul Fiqh;

Qaidah-Qaidah Istinbath dan

Ijtihad. Jakarta: Proyek Pembinaan

Prasarana dan Sarana Perguruan

Tinggi Agama/IAIN.

Kamali, M. H. (1991). Principles of

Islamic Jurisprudence. Cambridge:

The Islamic Text Society.

Low, S. (1906). A Vision of India.

London: Smith \& Elder.

Luckman, P. B. dan T. (1990). Tafsiran

Sosial Atas Kenyataan Risalah

Tentang Sosiologi Pengetahuan.

Jakarta: LP3ES.

Margareth Poloma. (2004). Sosiologi

Kontemporer. Jakarta: PT.Raja

Grafindo Persada.

Noer, D. (1973). The Modernist Muslim

Movement in Indonesia 1900-1942.

Kuala Lumpur: Oxford University

Press.

NU, P. (1992). Keputusan Munas Alim

Ulama \& Konbes Nahdlatul Ulama

di Bandarlampung 21-25 Januari

1992. Jakarta: PB NU.

Shidiq, S. (2011). Ushul Fiqh. Jakarta:

Kencana Prenada Media Group.

Sukidin, \& Basrowi. (2002). Metode

Penelitian Perspektif Mikro:

Grounded theory, Fenomenologi,

Etnometodologi, Etnografi,

Dramaturgi, Interaksi Simbolik,

Hermeneutik, Konstruksi Sosial,

Analisis Wacana, dan Metodologi

Refleksi. Surabaya: Insan Cendekia.

Suparno. (1997). Filsafat Konstruktivisme dalam Pendidikan. Yogyakarta:

Kanisius.

Syaltut, M. (1988). Al-Islam Aqidah wa Syari'ah, 4th edition. Cairo: Dar Syuruq.

Uwes, A. al-H. (n.d.). Al-Fiqh al-Isami baina al-Tatawwur wa al-Tsabat. Madinah: Syirkah al-Madinah alMunawwarah, t.t. 